\title{
Discussion on Some Problems in the Discipline Construction of Ideological and Political Education
}

\author{
Luo Yuyun \\ Fujian Jiangxia University, Fuzhou, Fujian, 350108, China
}

Keywords: Ideological and Political Education; Discipline Construction; Problems

\begin{abstract}
At present, the key transition period of deepening reform and adjustment of interest structure in China and the increasingly complex international situation have had strong impacts on the ideological and political views of Chinese college students. Some college students have problems like confusion of political beliefs, distortion of value orientation and money worship, and some have even negated and doubted the Marxist beliefs and the socialist road with Chinese characteristics. Therefore, the most urgent task for colleges and universities at present is to strengthen the ideological and political education of college students and improve the management level and efficiency on college students. By analyzing the existing problems in the discipline construction of ideological and political education, the author aimed to provide a certain reference for this aspect in China.
\end{abstract}

\section{Introduction}

Ideological and political education is very important because it relates to roads and ideals, culture and beliefs. Moreover, it is also a discipline closely related to the core accomplishment training of college students. Ideological and political education has long been in the higher education system and this concept has been deeply imprinted into the minds of college students, but there are still many problems in its practical application and development. These problems inevitably have negative impacts on the sound development of China's higher ideological and political education system, and they are also not conducive to the cultivation of college students and make them have noble ideological quality and correct political attitude. Therefore, it is significant to study the problems existing in the discipline construction of ideological and political education during this period.

\section{The basic theory of ideological and political education is less innovative}

The foundation of the subject of ideological and political education is the increasingly rich socialist political thought, and at the same time, its goal is to cultivate talents who are closely integrated with new ideas of the new era and equipped with good moral standards and qualities. Its foundation and goal determine that its basic educational theory must be constantly innovated to be in line with the times. At present, the research on ideological and political education still have problems in the essence of education, the grasp of objective educational laws, the nature of ideological and political disciplines and many other aspects. For example, can the current ideological and political education truly realize the educational significance to students? Or is it just to reproduce the dogma or copy the long and difficult concepts which are hard to understand? Should the basic education theory of ideological and political education be more abundant and profound in social connotation? And how to express it can further highlight the new tasks of ideological and political education given by the times? These are the unresolved issues in the current ideological and political education in its education nature [1].

In addition, the law of ideological and political education needs to be further understood. In the new era, ideological and political education has added many contents related to politics, civilization, society and economy. Its essence is not purely socialist ideological education or political concept education, but a kind of spiritual and cultural education based on an objective political ecology and 
with epoch-making ideological connotation. The law of ideological and political education should not be excessive at this level. Under the premise of insisting on the unity of macro and micro, the contemporary discipline of ideological and political education needs to deepen the law cognition of ideological and political education and reach a consensus on the characteristics of the discipline at an early date.

At the same time, there are also problems in the study of the basic category of the discipline of ideological and political education. Scientific ideological and political education researches have provided a realistic basis for this. Although there are many research results on the methods and process of ideological and political education, they mainly serve specific political teaching and thus are not so helpful for the establishment of the subject standard system of ideological and political education. At the same time, a teaching scope more scientific and outline-oriented is not clear [2].

\section{The research system of ideological and political education is incomplete}

With the nation's constant emphasis on education, it is extremely important to rationally apply educational research to improve education strength and enhance educational resources in reality. The value of educational research is not only that it can improve the process of educational research and perfect the results, but also that it has important value in promoting the development of teaching. Educational research contributes to synthesizing educational resources. It can systematically and scientifically analyze and refine the teaching experience and methods of frontline teachers to form universal concepts and achievements that contribute to the development of education. For example, it is possible to summarize the process and experience of teachers engaged in ideological and political education in dealing with different problems in the teaching process, and then to demonstrate and analyze them from different aspects based on modern ideological and political theories. In the end, a good teaching system or method can be derived for modern education.

At the same time, grassroots teachers, as the most direct contacts of education and educational resources, have more practical opportunities and innovative ideas. Currently, the ideological and political disciplines are not able to well perfect the academic research of ideological and political theories and promote the innovation of research results, and there are still many loopholes in the comprehensive research of political theory innovation and ideological and political teaching. This is reflected in the lack of innovation of educational research in ideological and political education. Innovation is mainly reflected in the innovation consciousness and ability of the project undertaker. In other words, he needs ability better than others to recreate the existing research results. This is because only a man has mental discernment can discover the value of educational research and realize its development. At the same time, he is also expected to have the ability to dare to break the stereotypes and not be bound by the rules and regulations in the process of research, thus forming good research ability. Finally, innovation is also reflected in the research results, that is, the research results must be the laws and methods that have not been recognized or discovered in specific fields. The innovation of ideological and political theory is limited by the domestic political system and the exploration of the history of ideas, so it has shortcomings.

\section{There are problems in the match of the teaching objectives of ideological and political courses with the goals of discipline construction}

The goal of ideological and discipline construction of political and ideological education has different connotations in different periods. In the new era, while comprehensively answering a series of advanced political ideas such as Marxism-Leninism and Mao Zedong Thought, it must closely integrate the Xi Jinping's theory of socialist construction, with the main goal of training a new generation of students with political comprehension, strong thinking logic and comprehensive quality. At the same time, it is necessary to strengthen the establishment of the research direction of this discipline, so as to better integrate ideological and political education into social culture and economic life, and form a three-dimensional cross-disciplinary system. Many colleges and 
universities have laid much stress on ideological and political education nowadays, but there are deviations in understanding. When ideological and political education is mentioned, the first reaction of the leaders of many schools is to give students a political lesson, to talk about principles or to give lectures, and they are also like to arrange all the moral, ideological and political education of college students for the counselors and party branches. They completely separate education and teaching from student management, which leads to inefficiency in ideological and political education [3].

The ideological and political education work carried out by many institutions has become a mere formality. This kind of education is not effective close to the actual life of college students, which makes them be very impatient, so that they feel that the school is always engaged in a vanity project. In addition, teachers are also lacking in the enthusiasm of implementing the goals of ideological and political education in the actual teaching process. The teachers of the theory courses about ideological and political education are the communicators of the party's line, principles and policies, and also the propagators of the party's ideology. They shoulder a very important mission and responsibility, so their comprehensive quality, theoretical level and teaching ability are directly related to the effectiveness of ideological and political education and also directly related to the ideological and political concept of college students. As far as the ideological and political education teachers at present are concerned, most of them have not received related professional training, and thus they lack the basis of professional ideological and political theory and theoretical cultivation. Their teaching is difficult to meet the needs of students in ideological and political learning. Moreover, their teaching methods are mostly single and boring, which is difficult to attract students' interest in learning.

\section{The high-quality online courses about ideological and political education is seriously insufficient}

The construction of the high-quality resource sharing course is an integral part of the national high-quality open curriculum construction project. This construction can realize the directional flow of educational resources and promote the transformation of teaching concepts. For some specific disciplines, it can give play to disciplinary advantages, create a better teaching atmosphere and promote the overall progress of teaching quality. On May 21, 2012, the General Office of the Ministry of Education issued the Implementation Measures for the Construction of the High-quality Resource Sharing Course (JiaoGaoTing [2012] No. 2) (hereinafter referred to as the Measures).The Measures proposed clear planning and deployment of the objectives, tasks, organization and implementation plans for the construction of the quality resource sharing course, and put forward corresponding measures for the development of the national-level high-quality resource sharing courses.

The particularity of the project construction of the high-quality resource sharing course requires a novel curriculum system, authoritative materials, and courses of this kind should be suitable for webcast and can adapt to students at different teaching levels. Therefore, it raises high requirements for the resource aggregation ability of course developers and their familiarity with the teaching of related professional fields. At the same time, it not only puts higher requirements on the teaching method and level of teachers, but also lays a new test on the students' understanding ability and the conversion of thinking habits [4].However, the current project of high-quality resource sharing course still adopt traditional teaching methods when the curriculum plan is designed and developed. In other words, theoretical lectures account for a large proportion in the teaching process and teachers generally cram their students with political theories in a stiff manner.

At the same time, the lack of reasonable teacher resources results in the fact that students cannot get good ability guidance and teaching assistance. The current resource sharing course of ideological and political education can only provide a theoretical framework for students but cannot help them improve their application capabilities. In the link of after-school learning, it is often impossible to achieve uniformity between the learning progress and ability improvement of students due to the large differences in their individual abilities, and there is also a lack of customizable 
training programs. It is then impossible to form a teaching system that meets students' ability requirements.

In addition, this course has insufficient promotion of traditional Chinese culture and poorly internationalized teaching resources. The construction of the high-quality resource sharing course should first be based on Chinese culture and China's national conditions. Chinese culture is an inseparable and important part of the world culture. It is all-inclusive, from various cultural and artistic forms like Chinese characters, music, painting and calligraphy to ethnic customs and sectarian beliefs. In the modern higher ideological education system, it is greatly significant to build a cultural education system and realize the goal of building the nation based on culture and strengthening the nation with culture. At present, the project construction of high-quality resource sharing course of ideological and political education in China is still mainly based on science and engineering disciplines. To some extent, it ignores the sharing course project construction of humanities and social science such as Chinese history, Chinese intellectual history and culture history. It therefore is impossible to form a targeted ability to promote traditional culture. The cultivation of students' humanities quality and ability is lacking in the actual construction process [5].

\section{The ideological and political education curriculum is not enough to understand the frontier of the society and the problem consciousness is not strong}

Problem consciousness and responsibility orientation are the main directions for the development of ideological and political education, but at present most schools only lay stress on various theories, without a practical framework. They turn a blind eye to the problems in the actual society and put ideological and political education above the facts, forming a large and empty theoretical model. However, ideological and political education needs to be closely integrated with social reality in order to have practical results. The proletarian revolutionaries of our older generation have created revolutionary theories with Chinese characteristics, which undoubtedly can be regarded as a typical example of the successful combination of theory and practice. In this sense, the actual ideological and political education will be like a tree without roots and water without a source if it separates from the social reality. For example, the anti-corruption campaign is very popular nowadays and there have been countless classic cases about the anti-corruption culture in thousands of years of Chinese history. For example, there are many important resources for the construction of a clean and honest government culture, such as "People do not snub a just man and staff dare not cheat a non-corrupt superior" "Fairness leads to cleanness and integrity gives birth to authority", "He who is honest must know shame and he who knows shame can be honest", and so on. These are all important resources for the construction of a clean and honest culture, but there is a lack of effective attention to similar social frontiers in the specific process of ideological and political education. Some cases are extremely vague and the explanations are not thorough in ideological and political classes. In particular, there is basically no process of using the corresponding political theory to analyze social phenomena. In most cases, teachers read item by item from the text and students study carelessly, lacking attention to the goal-oriented approach to ideological and political education. This shows that the current ideological and political education system is out of line with theory and practice, and ideological and political theory has not been used to help students form proper values and ideological connotations.

\section{Conclusions}

In summary, ideological and political education is an important link in the cultivation of talents, which is related to the formation of students' ideological systems and abilities. However, the cultivation of students' ideological awareness and ability is disturbed because there are still many problems in the teaching of ideological and political education. It is of great significance to improve the quality of ideological and political education, and different people have different views on the specific methods of implementation. In this paper, the author first presented analysis on this 
problem from five aspects, namely, the poor innovativeness of the basic theory related to ideological and political education, the incomplete ideological and political education research system, the problem of goal match between the ideological and political course teaching and the discipline construction, the lack of quality ideological and political online courses, and the weak awareness to ideological and political education courses. Through analyzing the existing problems in the construction of ideological and political education disciplines, the author hopes to help relevant educational institutions to find out the deficiencies and shortcomings in ideological and political education, so that they can explore proper ways to solve problems, achieve better ideological and political education and improve the quality of talent training.

\section{References}

[1] Wang Xuejun, Guo Shaojun. Key Problems and Strategies of Ideological and Political Education Discipline Construction [J]. School Party Construction and Ideological Education (Xuexiao Dangjian Yu Sixiang Jiaoyu), 2016(11): 11-14.

[2] Song Juncheng. Research on the Discipline Construction of Ideological and Political Education in Colleges and Universities [D]. Dalian University of Technology, 2015.

[3] Wang Yi. Three Problems Needing to Be Solved in the Further Strengthening the Discipline Construction of Ideological and Political Education [J]. Leading Journal of Ideological \& Theoretical Education, 2014(06): 14-16.

[4] Lin Bohai. Reflections on Deepening the Construction and Research of Ideological and Political Education Discipline [J]. Studies in Ideological Education, 2014(01): 15-17.

[5] Wang Xuejian, Li Dongpo. Problems and Reflections on the Disciplinary Construction of Ideological and Political Education under the New Situation [J]. Ideological \& Theoretical Education, 2013 (07):43-48.

[6] Li Wei, Ping Zhangqi. Some Thoughts on the Scientific Discipline Construction of Ideological and Political Education [J]. Journal of Socialist Theory Guide, 2012(04): 84-87. 